\title{
16. CRETACEOUS AND PLEISTOCENE BIVALVIA, DEEP SEA DRILLING PROJECT HOLES 415, 415A
}

\author{
Erle G. Kauffman, Department of Paleobiology, U.S. National Museum, Smithsonian Institution, \\ Washington, D.C.
}

\section{INTRODUCTION}

One of the great disappointments of the first 50 DSDP legs has been the apparent paucity of wellpreserved macrofossils in cores, especially those from the older Mesozoic levels where we seek the evolutionary rootstocks of the modern deep-sea biota. Only the calcitic prisms of inoceramid bivalves, singly or as clustered shell fragments, are commonly preserved in Jurassic and Cretaceous core samples-nonetheless reflecting the ubiquity of this group. Ammonites, including aptychi, compose the second most common macrofaunal element. Diverse assemblages of mainly small invertebrates such as those described by Kauffman (1976) from the Manihiki Plateau on Leg 33 are rarely encountered. Numerous such faunas may lie hidden in DSDP cores, but they have not been obvious from surficial examination or in microfossil washings. Only systematic splitting of DSDP cores at closely spaced intervals will possibly reveal quantities of additional macrofossil material.

Thus, we still know very little about the evolutionary history of macroinvertebrates from sediments over 75 per cent of the Earth's surface. The important challenge of documenting the ecological and biogeographic history of the deep-ocean biota, and its implications to biological theory and plate tectonics, cannot yet be met for lack of a good data base.

The poor record of macrofossils in DSDP cores magnifies the importance of thoroughly documenting the few assemblages that do come to light in initial surveys. Two small bivalve-dominated assemblages were discovered in Core 415-1, and in Core 415A-12, during Leg 50 drilling. The material is wholly of small, largely fragmented specimens, which are specifically indeterminate. Still, it provides important data for environmental interpretations of sediments deposited at the base of the continental slope off northwestern Africa. The ages determined from these assemblages, although not as precise as those determined on the basis of microfossils in this core, are compatible.

The bivalves discussed herein come from small core samples and washings kindly provided to me by Dr. W. V. Sliter of the U.S. Geological Survey, Menlo Park, California. Doubtless, much additional macrofossil material is still contained in the core at these and other levels but is not now available for study; for this reason, the following is a preliminary report. Work on DSDP macrobiotas has been partially supported by the Smithsonian Research Foundation under a grant to study the evolution of Mesozoic-Cenozoic marine ecological units in a variety of settings, including the deep sea. Specimens discussed in this report are housed in the U.S. National Museum type collections, in the Department of Paleobiology.

\section{BIVALVIA FROM SAMPLE 415A-12-1, 106-110 cm}

This thin interval of middle-Cenomanian mudstone is part of a slumped sequence of turbidites and is richly fossiliferous; fragments, and rarely whole shells, of bivalves not exceeding $13 \mathrm{~mm}$ in maximum diameter, strongly dominate the macrofossil assemblage. Fish scales and small fish teeth, echinoderm debris, and a single fragment of an arthropod claw or spine collectively compose about 5 per cent of the sample. Planktonic and benthic foraminifers, and a few ostracodes, occur in all samples and are moderately well preserved. The bivalve fraction is mainly composed of a small species of Ostrea (Ostrea) Linné. Most of the ostreid material consists of worn, semipolished, and obviously transported shell fragments of small adult(?) specimens which originally did not exceed an inch in maximum diameter. Very thin, fragile, juvenille shells of Ostrea (Ostrea) sp. down to $0.75 \mathrm{~mm}$ maximum diameter are also present in the sample, completely preserved. These were probably carried in suspension in turbidity flows which resulted in transport, breakage, and rounding of the larger specimens. Ostreid shell material is well preserved, without obvious solution or recrystallization structures. Dense laminated calcite predominates, but thin prismatic calcite layers are preserved in some specimens between laminated layers.

\section{Ostrea (Ostrea)}

Core 12 oyster specimens are typical of Ostrea (Ostrea) Linné (Figure 1), as emended by Stenzel (1971, p. N1138-N1139); species identification is impossible without larger and more complete valves and is especially difficult in such simple forms as these. The species is characterized by small size, low convexity of both valves, elongate-ovate shell form with height onethird greater than length, blunt slightly curved beaks and umbos, and nearly smooth shells bearing only faint irregular concentric lamellae, some of which are slightly raised above the shell surface. Internally, the right valve is characterized by a broad, low, subtriangular resilifer, gently arched in the center, and bearing prominent growth lines; the resilifer occupies the entire dorsal margin; auricles are absent. The posterior-adductormuscle insertion area is large, reniform or comma- 


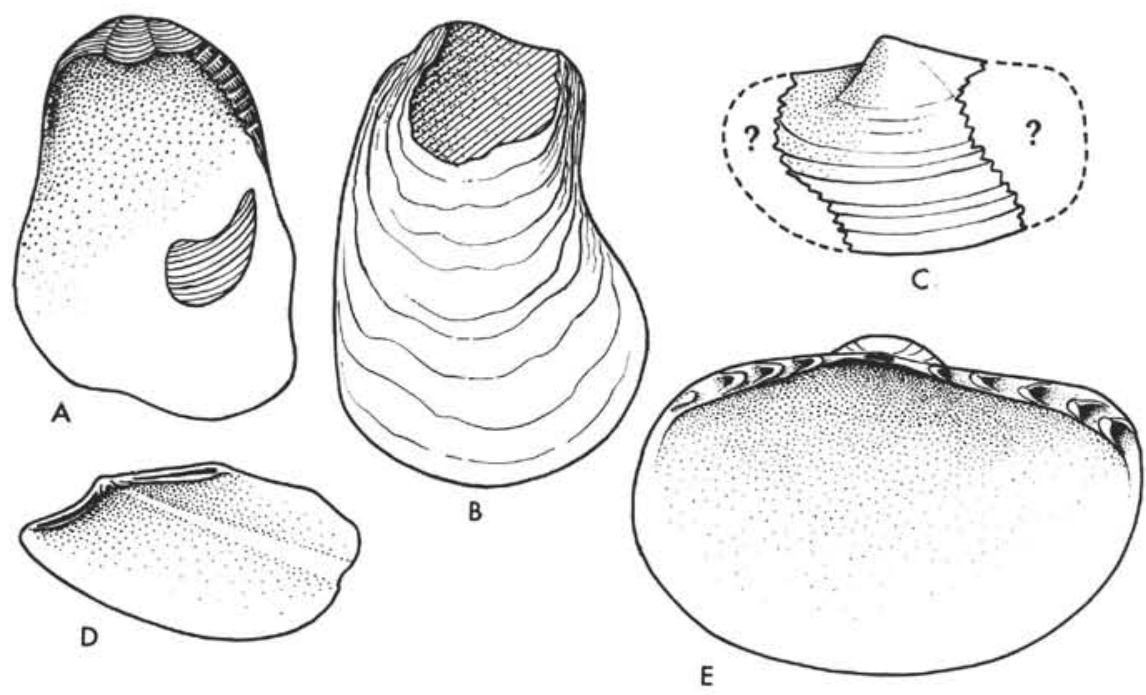

Figure 1. Enlarged cameralucida drawings and $(A, B)$ composite sketches of Leg 50 bivalves showing principal morphologic features of the best preserved Cenomanian Sample 415A-12-1, 106-110 cm: $(A-D)$, and Pleistocene Sample 415-1-2, $12 \mathrm{~cm}$ : (E) specimens. A,B-Right valve interior and left valve exterior $(\times 6)$, respectively, of Ostrea (Ostrea) sp. showing (A) adductor muscle scar, resilfier, anachomata, and (B) external form and ornamentation. USNM 242998. C-Laternula ? sp. (×4), internal mold, right valve, showing features of shape and ornament observed before partial breakage, original broken edge of specimen (jagged line), and inferred shell form (dashed line). USNM 243001. D-Schedotrapezium sp., interior view, composite mold of right valve $(\times 12.4)$, showing typical subtrapezoidal form, strong lateral teeth, possible weak cardinal dentition, and posteroventrally directed, weakly defined sulcus. USNM 243000. E-Tindaria sp. aff. T. miniscula Sanders and Allen, interior view ( $\times 42.4)$ drawn before breakage of specimen during mounting, showing shell form, chevron-shaped taxodont teeth and intervening sockets spread widely along thin hinge plate, and small pit below beaks in broad edentulous area between anterior and posterior rows of teeth. USNM 243002.

shaped, situated just posteroventral to the shell center, and well impessed. Low, rounded chomata are situated a short distance on either side of the resilifer, on the dorsolateral commissural margins of the right valve; thin ridglets mark the trace of the chomata on the lateral edge of the shell. The left valve interior is unknown. Attachment scars on the left valve are small and flat; attachment was to small, smooth or finely costate shell fragments.

Small Ostrea (Ostrea) sp. of this type are common throughout the Cretaceous and Cenozoic sequences. Although their ecology has not yet been fully documented in ancient deposits, Kauffman $(1967,1979$, p. 238) noted that small ostreids similar to those found in Core 12 dominated communities of midshelf depth (100-300 feet) in the western interior seaway of North America, and that deeper environments were characterized by small oysters of the genus Pycnodonte (Phygraea). This observation is compatible with the idea that sediments containing the oysters are largely turbidity-current deposits derived from the continental shelf of North Africa. Epibionts and endobionts are wholly lacking on the oyster shells recovered from Core 12, supporting a middle to outer-shelf origin for the shells, rather than a shallow-water origin. The specimens of $O$. (Ostrea) sp. are catalogued in the U.S. National Museum collections (USNM 242998).

Ostreinae (Costate sp.), gen. and sp. indet.

Two fragments of a larger, thicker-shelled oyster (genus indeterminate) appear to belong to a different species. The shell is subovate to subrounded (on the basis of juvenile-growth-line trace), and of moderately low convexity. Its surface bears moderately strong radial costae with a slightly sinuous trace. Costal crests are rounded and irregularly noded in adult growth. The costae are close set, about $1.5 \mathrm{~mm}$ apart on the largest fragment from Core 12. The shell form, and the spacing, subregular development, and rounded crests of the costae all suggest assignment to a costate species within the Ostreidae (Ostreinae) - perhaps some species of costate Ostrea (Ostrea), or ancestral Cretaceous species of Turkostrea or Cubitostrea (see illustrations in Stenzel, 1971, figs. J111-J117) - rather than to the 
more strongly plicate or costate Lophinae. Like other oyster-shell fragments, these are broken, worn, and semipolished; they are obviously transported and redeposited. Costate Cretaceous oysters are typical of shallow to moderately deep shelf depth communities (Kauffman, 1967, 1969). These specimens were probably carried from the North African shelf zone down the continental slope by Cenomanian turbidity currents. Specimens are catalogued as USNM 242999.

Three additional species of Cenomanian bivalves are represented only by internal and external molds in mudstone; the originally aragonitic shell material is completely dissolved or preserved as small, highly etched patches on the molds. All are single valves which are nearly complete, or very large fragments showing most of the morphologic features. These molds have been subsequently compressed and somewhat deformed. This fact, and lack of external shell features, makes determination even to genus difficult. The taxa to which these fossils seem most similar are all found in both shelf and deeper water (bathyal) environments. These forms conceivably could have lived near the depositional site at the base of the continental slope, and been redeposited as part of a turbidity flow; more likely, being thin light shells, they were carried largely in suspension from shelf zones by turbidity currents.

\section{Schedotrapezium sp.}

The best preserved non-ostreid bivalve is a single composite mold of a small, subtrapezoidal right valve with part of the dentition preserved (USNM 243000) (Figure 1). The specimen is $4.3 \mathrm{~mm}$ long, $2.1 \mathrm{~mm}$ high, and about $0.5 \mathrm{~mm}$ wide, strongly prosocline, and moderately prosogyrous. The small, blunt beak projects only slightly above the dorsal margin and is situated onefifth to one-quarter of the length from the anterior margin. The anterior flank is triangular and strongly projecting in front of the beaks; the ventral margin is broadly and asymmetrically rounded, the ventroposterior margin is moderately rounded, and the dorsoposterior margin is truncated in two places. The dorsolateral margins slope very gently away from the beak on either side and are straight to very slightly curved. Very faint growth lines constitute the only sculpture. A weak posteroventrally directed sulcus divides the posterior flank from the disc. A long, narrow, prominent lateral tooth extends subparallel to each dorsolateral margin for almost its entire length; traces of two very small cardinal teeth are possibly represented below the beaks.

This unusually shaped bivalve resembles few comparable known genera; among them the shell form and probable dentition most closely match Schedotrapezium Stewart, a genus previously known from the Upper Cretaceous of North America, West Africa(?), and Europe(?). The African occurrence is herein confirmed. The specimen is probably a juvenile, and is too poorly preserved for species determination.

\section{Laturnula? sp.}

Another bivalve taxon is represented by one internal mold of a small, very thin-shelled right valve (USNM
243001) with the posterior and (during preparation) anterior margin broken (Figure 1). The shell height is $8.5 \mathrm{~mm}$; before breakage a length of $11-12 \mathrm{~mm}$ was noted. Shell morphology suggests close similarity to Laternula Röding. The shell appears to have been elongate-ovate, with length one-third greater than height, anterior and posterior margins moderately rounded (according to growth line trace), and ventral and dorsal margins slightly curved. Convexity is very low; the surface is covered by irregularly developed, faint to moderately strong concentric growth lines. The beak is suberect to slightly opisthogyrate and projects slightly above the dorsal margin. The umbo is moderately inflated, subtruncated posteriorly, and terminates in a short but prominent umbonal fold between the dorsocentral and dorsoposterior flanks of the shell. No dentition or ligamenture is preserved; true Laternula is edentulous. Keen and Cox (1969, fig. F23-2) illustrate a typical example of the genus. The generic identity of the Core 12 specimen is questioned because of poor preservation, and species determination is impossible. The known Cretaceous Laternula are mainly associated with middle-shelf to upper-slope communities, but some are known from inner-shelf deposits. Laternula is known from Cretaceous to recent time.

\section{Phelopteria? sp.}

Two large fragments of a very thin-shelled, subquadrate, smooth, flat pteriacean bivalve were found in the Core 12 Cenomanian sample. The hinge line on one fragment has broad, shallow, widely spaced multivincular ligament pits, suggesting a genus within the Bakevelliidae, especially Phelopteria Stephenson; this genus is known from the Cretaceous of North America, West Africa, and Europe, and is a common component of communities throughout shelf and upper-slope environments. The large, flat posterior auricle preserved on one Core 12 fragment closely parallels that described for Cretaceous Phelopteria, as do other features of the external shell morphology. The specimens are too incomplete for species comparison, but they are about the size and shape of small upper Cenomanian species $(P$. minuta, $P$. quadrate sp. aff. $P$. minuta) recently described from the Greenhorn Formation of northwestern Oklahoma by Kauffman and Powell (1973, p. 50-52, pl. 8 , figs. 4, 6-8). The specimens are catalogued in the U.S. National Museum (USNM 243002).

\section{Summary}

Five taxa of small bivalves are present in Sample 12-1, 106-110 cm: Ostrea (Ostrea) sp.; Ostreinae (costate sp.), gen. and sp. indet.; Schedotrapezium sp.; Laternula? sp.; and Phelopteria? sp. All were previously known from the Cretaceous and some are restricted to the Upper Cretaceous, suggesting an age compatible with that inferred from microfossils. The material is, in general, poorly preserved and composed of worn shell fragments from larger specimens, and nearly complete shells of small (less than $10 \mathrm{~mm}$ ) and (or) very thinshelled specimens. Collectively, the assemblage suggests that the fauna lived in middle- to outer-shelf en- 
vironments during the Cretaceous, e.g., comparable to deeper portions of epicontinental seas like those of the western interior of North America and western and central Europe. The assemblage is not similar to Cretaceous (Kauffman, 1976) or modern abyssal or bathyal assemblages (e.g., Knudsen, 1967, 1970). These factors imply secondary transport of the assemblage from shelf depths, probably by suspension in turbidity currents, to the base of the continental slope of northwest Africa during the Cenomanian; this is compatible with physical-sedimentology evidence.

\section{A PLEISTOCENE TINDARIA FROM SAMPLE 415-1-2, $12 \mathrm{~cm}$}

A single, very well preserved, small bivalve shell was obtained from washings at this locality by V. W. Sliter. Fortunately, the specimen was identified, described, and sketched (Figure 1) before it broke into several pieces during final examination. The specimen is translucent and extremely thin shelled, elongate-ovate in outline, with the length $(1.9 \mathrm{~mm})$ nearly one-third greater than the height; inflation is moderate and greatest in the umbonal area. The shell surface is smooth except for very faint concentric growth lines, subregularly and closely spaced, over the entire shell. A narrow, lanceolate, well-defined, moderately excavated escutcheon bears the external ligamental groove. The ligament is situated posterior to the moderately projecting, incurved beak. Internally, a very thin hinge plate supports widely spaced, chevron-shaped (taxodont) teeth with deep sockets in each tooth between the lateral extensions of each chevron and broad interspaces between the teeth; five posterior teeth, and four anterior teeth, only three of which are chevron shaped, occur on the hinge plate. A small semicircular depression lines below the beak of the right valve on the hinge plate in the center of a broad edentulous area between anterior and posterior rows of teeth.

This delicate shell clearly belongs to the genus Tindaria Bellardi, 1875 , and is only slightly different from T. miniscula Sanders and Allen, a living species dredged from the Angola Basin, Atlantic II cruise, station 197, at depths between 4565 and 4595 meters. The DSDP specimen is slightly more elongate, with the beak slightly less projecting, and has one less tooth on the posterior part of the hinge plate than $T$. miniscula (see Sanders and Allen, 1977, text-figs. 23, 27). Otherwise the two are identical in size, inflation, ornamentation, general outline, and nature of the dentition. The Pleistocene bivalve is either a population variant of $T$. miniscula, or very closely related and ancestral to it.

The most important aspect of the occurrence of Tindaria sp. aff. T. miniscula is that it is an in situ lowerbathyal and (or) upper-abyssal mollusk associated with Pleistocene sediments in Hole 415 that is similar in morphology, preservation, and ecology to modern forms. Its known depth range ( $4565 \mathrm{~m}$ to $4595 \mathrm{~m}$ ) is somewhat greater than the present water depth of Site 415 (2794 m) but the environments are essentially compatible. $T$. miniscula may range higher in the bathyal zone; its geographic and depth limits are still poorly known, it being a rare and only recently discovered form.

\section{CONCLUSION}

Fossil mollusks, although rare and small in DSDP cores, provide useful and interesting biostratigraphic and ecological information. Even in the sparse and poorly preserved samples studied here, both the Cenomanian (Upper Cretaceous) and Pleistocene molluscan assemblages contained taxa which provided an age designation compatible with the designations made on the basis of the microfossils. Both provided an independent check on the environment of deposition of the sediments. The Cenomanian assemblage of Ostrea (Ostrea) sp., Ostreinae (costate) sp., Schedotrapezium sp., Laternula? sp., and Phelopteria? sp. is clearly of middle- to outer-shelf origin and obviously has been reworked by turbidity currents downslope into deeperwater environments. The Pleistocene Tindaria sp. aff. T. miniscula is characteristic of living lower-bathyal to upper-abyssal forms occurring at depths similar to those of the drill site; it was not transported and redeposited.

I urge a greater awareness of the value of macrofossils in the interpretation of DSDP cores and hope that this contribution will encourage others to intensify the search in DSDP core material for macrofossils and thus increase the number of discoveries made. One cannot help but speculate that a wealth of important biological data bearing on age determination, environmental analysis, and on understanding the evolution of oceanic, especially deep-sea, communities, lies hidden in existing and forthcoming DSDP core material.

\section{REFERENCES}

Kauffman, E. G., 1967. Coloradoan macroinvertebrate assemblages, central western interior, United States. In Kauffman, E. G. and Kent, H. C. (Co-convenors), Paleoenvironments of the Cretaceous Seaway: a symposium, Colorado School of Mines, Spec. Publ., preprints of papers, p. 67-143.

1969. Cretaceous marine cycles of the western interior, Mountain Geol., v. 6, 226-245.

1976. Deep-sea Cretaceous macrofossils: Hole 317A, Manihiki Plateau. In Schlanger, S. O., Jackson, E. D., et al., Initial Reports of the Deep Sea Drilling Project., v. 33: Washington (U.S. Government Printing Office), p. 503-535.

Kauffman, E. G. and Powell, J. P., 1977. Part 2. Paleontology. In Kauffman, E. G., Hattin, D. E., and Powell, J. D. (Eds.), Stratigraphic, paleontologic, and paleoenvironmental analysis of the Upper Cretaceous rocks of Cimmaron County, northwestern Oklahoma, Geol. Soc. Am. Mem. 148 , p. 47-150.

Keen, M. and Cox, L. R., 1969. Family Laternulidae Hedley, 1918. In Moore, R. C. (Ed.), Treatise on invertebrate paleontology, Part N, v. 2. Mollusca 6, Bivalvia: Geol. Soc. Am. (Univ. Kansas Press), p. N8; 44-N845.

Knudsen, J., 1967. The deep-sea Bivalvia, Brit. Mus. (Nat. Hist.), Sci. Rept. J. Murray Exped., 1933\#1934, v. 11, p. 237-343.

1970. The systematics and biology of abyssal and hadal Bivalvia, Galathea Rept., v. 11, p. 7-241. 
Sanders, H. L. and Allen, J. A., 1977. Studies on the deep sea Protobranchia (Bivalvia); The Family Tindariidae and the genus Pseudotindaria. Harvard Univ., Bull. Mus. Comp. Zool., v. 148, p. 23-59.
Stenzel, H. B., 1971. Oysters. In Moore, R. C. (Ed.), Treatise on invertebrate paleontology: Part $\mathrm{N}, \mathrm{v} .3$, Mollusca 6, Bivalvia. Geol. Soc. Am. (Univ. Kans. Press), p. iv + N953-N1224. 